\title{
Occurrence of Airborne Bacteria and Pathogen Indicators during Land Application of Sewage Sludge
}

\author{
SURESH D. PILLAI, ${ }^{1 *}$ KENNETH W. WIDMER, ${ }^{1}$ SCOT E. DOWD, ${ }^{1}$ AND STEVEN C. RICKE ${ }^{2}$ \\ Environmental Science Program, Texas A\&M University Research Center, El Paso, ${ }^{1}$ and \\ Poultry Science Department, Texas A\&M University, College Station, ${ }^{2}$ Texas
}

Received 13 July 1995/Accepted 25 October 1995

\begin{abstract}
Glass impingers (AGI-30) were used at a commercial sludge application site to determine the levels of airborne bacteria and pathogen indicators. Even though heterotrophic bacteria averaged $10^{5} \mathrm{CFU} / \mathrm{m}^{3}$, none of the sites showed the presence of Salmonella spp. or indicators such as fecal coliforms or coliphages. Indicators such as $\mathrm{H}_{2} \mathrm{~S}$ producers and pathogenic clostridia were present in locations having significant physical agitation of the sludge material. PCR-based ribotyping using the $16 \mathrm{~S}-23 \mathrm{~S}$ interspacer region is a promising method to identify the genetic relatedness and origins of airborne clostridia.
\end{abstract}

Municipal sewage sludges are routinely utilized on agricultural lands in various parts of the world. In the United States, as much as $33 \%$ of the municipal sludge produced is applied onto agricultural lands $(22,25)$. With the ban on ocean sludge dumping and the increasing restrictions on landfills, disposal onto land surfaces becomes almost the only alternative and is expected to increase in the future (26). One of the primary hazards associated with sewage sludges is the accumulation of pathogenic microorganisms. Though there have been numerous reports on pathogen survival in agricultural lands and waterways exposed to sewage sludges $(13,14,23,27)$, there is, surprisingly, only limited information on the occurrence of airborne microbial pathogens during sludge application. Most of the available information is based on aerosol studies conducted near wastewater treatment plants, at effluent spray irrigation sites, and within waste-handling facilities $(6,17,20)$. There are public concerns regarding the potential exposure to airborne microbial pathogens within population centers surrounding the application sites. The sludge application program in Sierra Blanca, Tex., is one of the largest commercial operations in the United States, covering approximately $7.2 \times 10^{7}$ $\mathrm{m}^{2}$ of rangeland (8). Dewatered, anaerobically digested municipal sewage sludge from New York City is transported by rail to Sierra Blanca, where it is surface applied as a semi-solid "cake" form on arid rangelands at an annual rate of 3 dry tons (ca. $2,700 \mathrm{~kg}$ ) $/ 4 \times 10^{3} \mathrm{~m}^{2}$. Since this rangeland is located in an arid, windswept region, the potential for airborne microbial pathogens could be considered high $(5,21)$. There are serious public concerns of airborne transmission of microbial pathogens to the neighboring town of Sierra Blanca, which is located approximately $4 \mathrm{mi}(\mathrm{ca} .6 \mathrm{~km})$ to the closest sludge application area.

To determine if sludge application results in airborne bacterial pathogens at locations around the application sites, a 4-month monitoring study was initiated in August 1994. The primary objective of the study was to determine the abundance of the airborne bacterial pathogens and indicator organisms at various locations within and around the site, as well as to determine if sludge-derived bacterial pathogens were detectable at the rangeland-population interface. A secondary objec-

\footnotetext{
* Corresponding author. Mailing address: Environmental Science Program, Texas A\&M University Research Center, 1380 A\&M Circle, El Paso, TX 79927. Phone: (915) 859-9111. Fax: (915) 859-1078. Electronic mail address: sureshp@laguna.epcc.edu.
}

tive of the study was to evaluate the efficacy of using the 16S-23S interspacer region as a tool to ribotype airborne clostridia to assist in identifying their origins.

The Sierra Blanca Ranch in far west Texas is in the Chihuahuan Desert, which is characterized by limited precipitation, high summer air temperatures, high wind velocities, and low relative humidities (28). The ranch covers approximately $5 \times$ $10^{8} \mathrm{~m}^{2}$, of which only $7.2 \times 10^{7} \mathrm{~m}^{2}$ is currently being used for sludge application. Wind velocities on the ranch rarely exceed $32 \mathrm{~km} / \mathrm{h}$ (average around $8 \mathrm{~km} / \mathrm{h}$ ), though occasional gusts of up to $65 \mathrm{~km} / \mathrm{h}$ have been recorded. Five sampling locations were chosen, namely, the "Upwind" (representing sites upwind of the sludge application areas), the "Rangeland-Population Interface" (representing the interface between the sludge application area and the population center at Sierra Blanca), the "Old Application" locations (representing areas where sludge had been previously applied), the "Sludge Application" areas (representing locations directly under current sludge application), and the "Hopper Loading" sites where mechanized sludge spreaders (hoppers) are loaded with front-end loaders. The Hopper Loading sites served as locations with maximal physical disturbance of both the sludge material and the soil and therefore had the maximum potential for generating airborne microorganisms.

The sampling was based on the American Society for Testing and Materials method for sampling airborne microorganisms at municipal solid-waste facilities (4). The AGI-30 impinger (Ace Glass, Vineland, N.J.) was employed, with the samples being concentrated (20 min at 12 liters/min) in $20 \mathrm{ml}$ of $0.1 \%$ peptone. Peptone was used to aid in resuscitating potentially stressed organisms. Impingement rather than impaction was chosen since it provided protection against microbial injury during sampling and transportation (29). A total of 15 sampling trips were made during the study, with at least two trips to each of the five locations. Five replicate air samples were collected during each trip. The procedure was as follows: two impingers sampling simultaneously for $20 \mathrm{~min}$, followed by two more impingers (also sampling simultaneously) for $20 \mathrm{~min}$, and the last impinger sampling for $20 \mathrm{~min}$. The entire procedure, including equipment setup, took no more than $70 \mathrm{~min}$. The impingers were always positioned downwind and $1.5 \mathrm{~m}$ above the ground, which corresponds to the average breathing height of an individual. Basic meterological measurements such as wind speed, temperature, and other weather conditions were obtained with hand-held instruments and from an on-site 
TABLE 1 . Weather conditions and airborne bacterial populations at the sampling sites ${ }^{a}$

\begin{tabular}{|c|c|c|c|c|c|c|c|}
\hline $\begin{array}{l}\text { Location and date } \\
(\mathrm{mo} / \mathrm{day} / \mathrm{yr})\end{array}$ & $\begin{array}{l}\text { Primary wind } \\
\text { direction }\end{array}$ & $\begin{array}{l}\text { Mean relative } \\
\text { humidity }(\%)\end{array}$ & $\begin{array}{l}\text { Mean air } \\
\text { temp }\left({ }^{\circ} \mathrm{C}\right)\end{array}$ & $\begin{array}{l}\text { Mean wind } \\
\text { speed }(\mathrm{mph})^{b}\end{array}$ & $\begin{array}{l}\text { Clostridium } \\
\text { CFU } / \mathrm{m}^{3 c}\end{array}$ & $\begin{array}{l}\text { Heterotrophs } \\
\left(\mathrm{CFU} / \mathrm{m}^{3}\right)^{d}\end{array}$ & $\begin{array}{c}\mathrm{H}_{2} \mathrm{~S} \\
\text { production }^{e}\end{array}$ \\
\hline \multicolumn{8}{|l|}{ Upwind } \\
\hline $10 / 12 / 94$ & South & 18 & 22 & 2.96 & bd & $3.3 \times 10^{3}$ & - \\
\hline $10 / 19 / 94$ & South & 45 & 21 & 0.48 & bd & $1.7 \times 10^{5}$ & - \\
\hline \multicolumn{8}{|c|}{ Sierra Blanca Interface } \\
\hline $8 / 12 / 94$ & South & 39 & 27 & 2.56 & bd & $5.4 \times 10^{2}$ & - \\
\hline $8 / 30 / 94$ & South & 35 & 28 & 2.12 & bd & $2.1 \times 10^{5}$ & - \\
\hline $10 / 27 / 94$ & West & 53 & 18 & 2.58 & bd & $1.0 \times 10^{4}$ & - \\
\hline \multicolumn{8}{|l|}{ Application Site } \\
\hline $8 / 23 / 94$ & West & 38 & 29 & 2.3 & bd & $2.7 \times 10^{4}$ & - \\
\hline $9 / 12 / 94$ & South & 34 & 28 & 2.82 & bd & $2.5 \times 10^{5}$ & - \\
\hline $10 / 4 / 94$ & South & 33 & 27 & 4.42 & bd & $4.2 \times 10^{3}$ & - \\
\hline $11 / 7 / 94$ & South & 24 & 21 & 5.14 & bd & $2.2 \times 10^{4}$ & - \\
\hline \multicolumn{8}{|l|}{ Hopper Loading } \\
\hline $9 / 6 / 94$ & South & 64 & 24 & 3.8 & bd & $5.6 \times 10^{1}$ & + \\
\hline $9 / 15 / 94$ & West & 39 & 25 & 4.82 & $5.17 \times 10^{2}$ & $6.3 \times 10^{5}$ & + \\
\hline $10 / 6 / 94$ & West & 33 & 22 & 4.11 & $4.98 \times 10^{2}$ & $1.8 \times 10^{5}$ & + \\
\hline $11 / 9 / 94$ & North & 24 & 17 & 3.21 & bd & $7.0 \times 10^{4}$ & - \\
\hline \multicolumn{8}{|l|}{ Old Application Site } \\
\hline $9 / 8 / 94$ & North & 37 & 28 & 2.56 & bd & $5.7 \times 10^{4}$ & - \\
\hline $9 / 30 / 94$ & South & 15 & 29 & 2.89 & bd & $7.6 \times 10^{3}$ & - \\
\hline
\end{tabular}

${ }^{a}$ Salmonella spp. and fecal bacteria were below detection limit $\left(168 \mathrm{MPN} / \mathrm{m}^{3}\right)$ for all locations and dates.

${ }^{b} 1 \mathrm{mph}=1.609 \mathrm{~km} / \mathrm{h}$.

${ }^{c}$ bd, below detection limit $\left(33 \mathrm{CFU} / \mathrm{m}^{3}\right)$.

${ }^{d}$ Detection limit $=21 \mathrm{CFU} / \mathrm{m}^{3}$.

$e+, \mathrm{H}_{2} \mathrm{~S}$ producing; - , not $\mathrm{H}_{2} \mathrm{~S}$ producing.

meterological facility (Table 1 ). The samples were transported on ice and processed within $4 \mathrm{~h}$. The 20 -ml samples were initially concentrated to between 0.5 and $5.7 \mathrm{ml}$ with Centriprep-50 concentrators (Amicon, Beverly, Mass.) by a twostep centrifugation procedure $(1,000 \times g$ for 5 min and $1,000 \times$ $g$ for $1 \mathrm{~min})$ to enhance the detection sensitivity. Aliquots of the concentrated sample were analyzed for specific microbial populations.

Aerobic heterotrophic bacteria. Aliquots $(100 \mu \mathrm{l})$ of the undiluted sample and 1:25 and 1:625 dilutions were plated on R2A media (Difco, Detroit, Mich.) and incubated at $27^{\circ} \mathrm{C}$ for 5 days. These populations ranged from $6.4 \times 10^{1}$ to $3.1 \times 10^{6}$ $\mathrm{CFU} / \mathrm{m}^{3}$ at the various locations at the site (Table 1$)$. The Hopper Loading sites exhibited the highest number, with populations averaging $2.2 \times 10^{5} \mathrm{CFU} / \mathrm{m}^{3}$, while the Upwind site exhibited the lowest numbers, averaging $8.7 \times 10^{4} \mathrm{CFU} / \mathrm{m}^{3}$. The higher levels of airborne bacteria at the Hopper Loading site could be attributed to the physical agitation of the sludge material during sludge-loading operations. There was, however, no direct correlation between wind speed and bacterial population densities $\left(r^{2}=0.05\right)$. Note that, under low-wind conditions, the heterotroph counts were actually higher than those obtained under stronger winds. Grinshpun et al. (10) have reported that the "aspiration efficiency" of air samplers generally declines under strong wind conditions. There was, however, variability in bacterial abundance at a single site on different days (Table 1), which other studies have also reported as being characteristic of bioaerosols $(6,7,18,24)$. Since the sampling at the Hopper Loading site was performed approximately 15 to $30 \mathrm{~m}$ downwind of the sludge-loading operations, these values could represent the maximum airborne bacterial loading potential during physical agitation of sludge material (under similar weather conditions) during these operations. These airborne heterotrophic bacterial levels are greater than those reported by Brenner et al. (6), who reported bacterial levels ranging from $10^{2}$ to $10^{4}$ at a wastewater spray irrigation facility (6). Possible reasons for the elevated numbers in this study are that the samplers were operated close to their optimal sampling flow rate, the R2A medium was a better isolation medium, and impingement may have resulted in a breakup of larger-sized particles resulting in higher CFU counts (18).

Salmonella spp. and pathogen indicators. The standard fivetube most probable number (MPN) method (3) was adopted for enumerating Salmonella spp., fecal coliforms, and fecal streptococci with 1-ml aliquots of the 1:25, 1:625, and 1:15,625 dilutions as inocula. Since hydrogen sulfide-producing bacteria (Salmonella, Citrobacter, Clostridium, Proteus, Edwardsiella, and some Klebsiella species) have been shown to be associated with the presence of fecal contamination (19), the commercially available PathoScreen medium (Hach Co., Loveland, Colo.) was utilized as a presence-absence assay for detecting $\mathrm{H}_{2} \mathrm{~S}$ producers. One hundred microliters of the concentrated sample was incubated with $5 \mathrm{ml}$ of the reconstituted media at $27^{\circ} \mathrm{C}$ for a minimum of $48 \mathrm{~h}$ before confirmation. Since clostridial spores present in sewage sludges serve as a better indicator for fecal contamination than coliforms $(13,15)$, pathogenic clostridia were enumerated by using the selective Clostrisel agar (Acumedia) and $100 \mu l$ of the concentrated sample was used as the inoculum. The plates were incubated anaerobically at $35^{\circ} \mathrm{C}$ for at least $48 \mathrm{~h}$ before enumeration. Two methods, namely, the colorimetric (presence-absence) assay (16) and the soft agar overlay (1), were employed to detect coliphages. Escherichia coli ATCC 13706 (C-3000) and ATCC 15597 were used in the agar overlay method as hosts to detect somatic and male-specific $\left(\mathrm{F}^{+}\right)$coliphages, respectively, along with $0.1 \mathrm{ml}$ of sample inoculum.

None of the sites showed the presence of Salmonella spp. Hydrogen sulfide producers and Clostridium spp. $\left(5.1 \times 10^{2}\right.$ $\mathrm{CFU} / \mathrm{m}^{3}$ ) were detected only at the Hopper Loading site (on three out of four days) (Table 1). Even at this site, none of the samples were positive for fecal coliforms or fecal streptococci. It is interesting that even though sewage pathogen indicators such as Clostridium spp. and hydrogen sulfide producers were detected at the Hopper Loading site (Table 1), none of the 
samples showed the presence of other indicators such as fecal coliforms or fecal streptococci. These results further confirm that clostridia and $\mathrm{H}_{2} \mathrm{~S}$ producers are better indicators of airborne sewage- or sludge-derived material than traditionally employed bacterial indicators $(13,15)$. It must be mentioned that the absence of fecal coliforms and fecal streptococci in the air samples is important, considering that the levels of these indicator bacteria in the sludge piles at the Hopper Loading site were $2.3 \times 10^{4}$ MPN Salmonella spp., $1.1 \times 10^{8} \mathrm{MPN}$ fecal coliforms, and $3.5 \times 10^{6} \mathrm{MPN}$ fecal streptococci per $\mathrm{g}$ of wet sludge, respectively.

None of the sites were positive for $\mathrm{F}^{+}$or somatic coliphages. Brenner et al. (6) have also reported recovering very low numbers of coliphages ( 0 to $9 \mathrm{PFU} / \mathrm{m}^{3}$ ) even when sampling large air volumes. Unlike spray irrigation sites where there is a greater propensity for aerosol generation, the potential for virus transmission from sludge application sites under lowwind conditions may be minimal. Fannin et al. (9) have also reported that they were unable to detect enteroviruses from as much as $190 \mathrm{~m}^{3}$ of air, compared to the AGI sampler, which collects only $0.24 \mathrm{~m}^{3}$ during impingement.

Ribotyping of airborne clostridia. To determine whether the differences in the 16S-23S interspacer region's length could be utilized as a tool to distinguish airborne clostridia and thereby identify their possible sources, the clostridial isolates from the air and sludge samples were ribotyped by using PCR primers specific to this region. Gurtler (11) had previously demonstrated that the variable length of the $16 \mathrm{~S}-23 \mathrm{~S}$ interspacer region of rRNA operons could serve as an effective tool to highlight genetic differences between clostridial strains. For ribotyping, the primer pair 5' TTG TAC ACA CCG CCC GTC and 5' CCT TTC CCT CAC GGT ACT G (specific to the spacer region) was employed in PCR amplifications using the following reaction conditions: $95^{\circ} \mathrm{C}$ for $1 \mathrm{~min}, 55^{\circ} \mathrm{C}$ for $1 \mathrm{~min}$, and $70^{\circ} \mathrm{C}$ for $3 \mathrm{~min}$ (40 cycles). The reaction products were resolved on a $2 \%$ submarine NuSieve (FMC Bioproducts, Rockland, Maine) agarose gel. In order to differentiate isolates having similar ribopatterns, the PCR products from these isolates were restriction digested with HindIII (Boehringer Mannheim) at $35^{\circ} \mathrm{C}$ for $60 \mathrm{~min}$ and resolved on a $1 \%$ agarose gel.

A total of 13 different Clostridium isolates were obtained during the course of this study, some directly from sludge material (at the Hopper Loading site) and four isolates from the air samples collected on 15 September and 6 October 1994. The airborne isolates were ribotyped to determine whether they were genetically related to those isolates obtained from the sludge samples. Figure $1 \mathrm{~A}$ is the ribopattern for the clostridial samples collected on the various days. The isolates from the air samples (lanes G, H, I, and J) (collected on 15 September and 6 October) are clearly distinct from those from the sludge material (lanes B, C, D, E and F) (collected on 15 September), suggesting they are genetically distinct or unrelated (11). It is, however, possible that the overall genetic similarities between the sludge and the air sample isolates may have been missed since a larger number of isolates was not screened. Since it was not possible to distinguish the relatedness of the different airborne clostridial isolates by the interspacer region amplification alone, restriction digestions were performed on the amplified products. Figure $1 \mathrm{~B}$ is the restriction digest pattern. It is evident (on the basis of the sizes of the primary bands at around $450 \mathrm{bp}$ ) that the airborne clostridial isolates obtained on 15 September 1994 were closely related to airborne clostridia obtained almost 3 weeks later on 6 October 1994, suggesting some common origin which was unidentifiable. These results indicate that sequence variations of the $16 \mathrm{~S}-23 \mathrm{~S}$ interspacer region could be an effective tool to
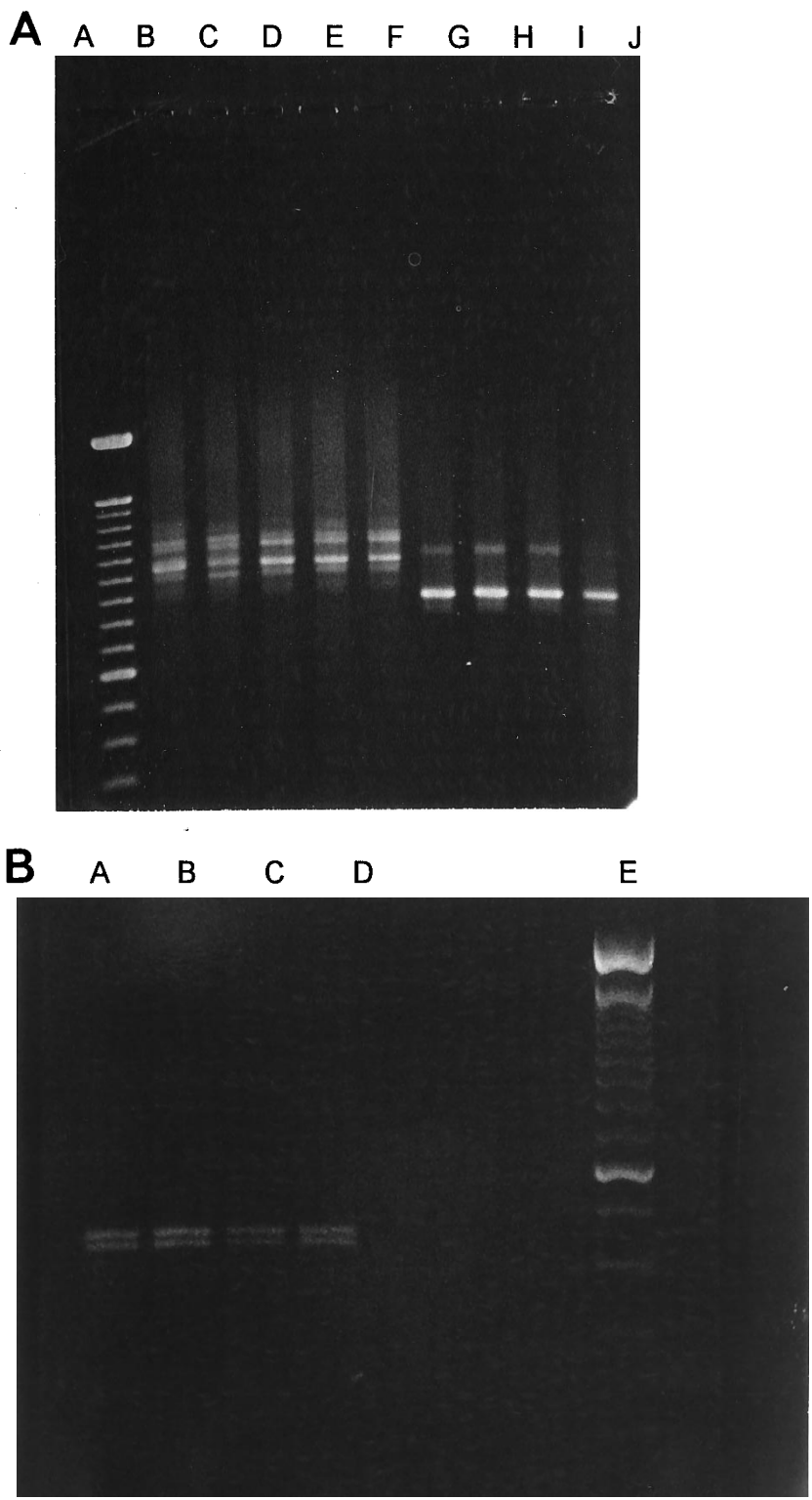

FIG. 1. (A) Ribopattern of clostridial isolates obtained on two sampling days at the Hopper Loading site. Lanes: A, 100-bp ladder; B, C, D, E, and F, sludge-derived clostridial isolates; $\mathrm{G}$ through $\mathrm{J}$, clostridial isolates from air samples (G and H, 15 September 1994; I and J, 6 October 1994). (B) HindIII digest of PCR product from clostridial isolates obtained from sludge and air samples obtained on two sampling days at the Hopper Loading site. Lanes: A and B, clostridial isolates obtained on 15 September 1994; C and D, clostridial isolates obtained on 6 October 1994; E, 入/HindIII and EcoRI.

rapidly determine (via PCR) the genetic relatedness of airborne clostridia, which could have significant epidemiological value.

The results suggest that land application of municipal sludges at 3 dry tons (ca. $2,700 \mathrm{~kg}$ ) $/ 4 \times 10^{3} \mathrm{~m}^{2}$ poses little risk of airborne transmission of bacterial pathogens (under relatively similar geographical and weather conditions) and that the population center ( $4 \mathrm{mi}$ [ca. $6 \mathrm{~km}$ ] downwind) is not impacted by airborne bacterial pathogens from the sludge application area. The absence of sludge-derived airborne pathogens at any of the locations, especially the interface, is supported by other studies conducted to measure dust generation during sludge 
application and its potential impact on the interface. Harris (12) has reported that only $0.026 \mathrm{~g}$ of particulate material accumulated in samplers after 25 days of continuous sampling. It is clear, however, that physical agitation of sludge material (as in the Hopper Loading site) could result in the generation of a large number of diverse bacterial populations in the immediate vicinity, raising questions of possible sludge-handling worker exposure. The results confirm the importance of using alternate pathogen indicators such as hydrogen sulfide producers and pathogenic clostridia in addition to traditional indicators such as fecal coliforms and fecal streptococci. Though more sophisticated and expensive air samplers are available, the AGI-30 sampler, even with its limitations (18), can be extremely effective at sampling airborne bacteria. Impingement into liquid media provides versatility, in that aliquots can be analyzed for a variety of different bacterial genera and for molecular analyses (2). The study demonstrates that ribotyping airborne clostridia by using the $16 \mathrm{~S}-23 \mathrm{~S}$ interspacer region provides two significant advantages. First, the sequence variation within the clostridial interspacer region can be effectively used to type clostridia; second, since a number of studies have indicated that clostridia are better indicators of sludge material than traditional pathogen indicators, clostridium detection and ribotyping could serve as an excellent approach for identifying the presence of airborne pathogens and determining their origins or sources.

The technical assistance of Jacob Pena is gratefully acknowledged. We thank Bob Carlile (Merco Joint Venture) for his helpful discussions and Corey Moffett (Texas Tech University) for providing detailed weather information.

This work was supported by a research grant from Merco Joint Venture, New York, to S.D.P., and funds from the Texas Agricultural Experiment Station of the Texas A\&M University System (project TEX 08239).

\section{REFERENCES}

1. Adams, M. H. 1959. Assay of phage by agar layer method, p. 450-454. In Bacteriophages. Interscience Publishers, Inc. New York.

2. Alvarez, A. J., M. P. Buttner, and L. D. Stetzenbach. 1995. PCR for bioaerosol monitoring: sensitivity and environmental interference. Appl. Environ. Microbiol. 61:3639-3644.

3. American Public Health Association. 1992. Standard methods for the analysis of water and wastewater, 18th ed. American Public Health Association, Washington, D.C.

4. American Society for Testing Materials. Standards on materials and environmental microbiology, 2nd ed. American Society for Testing and Materials, Philadelphia, $\mathrm{Pa}$

5. Bitton, G. 1980. Introduction to environmental virology, p. 200-242. John Wiley \& Sons, Inc., New York.

6. Brenner, K. P., P. V. Scarpino, and C. S. Clark. 1988. Animal viruses, coliphages, and bacteria in aerosols and wastewater at a spray irrigation site. Appl. Environ. Microbiol. 54:409-415.

7. Buttner, M. P., and L. Stetzenbach. 1993. Monitoring airborne fungal spores in an experimental indoor environment to evaluate sampling methods and the effects of human activity on air sampling. Appl. Environ. Microbiol. 59:219-226.

8. Carlile, B. L. Personal communication

9. Fannin, K. F., S. C. Vanna, and W. Jakubowski. 1985. Effect of an activated sludge wastewater treatment plant on ambient air densities of aerosols containing bacteria and viruses. Appl. Environ. Microbiol. 49:1191-1196.

10. Grinshpun, S. A., G. N. Lipatov, T. J. Semenyuk, and V. I. Yakimchuk. 1991. Pecularities of Lyocopodium spores sampling from the ambient atmosphere: physical effects and problems of representativeness. Grana 30:424-429.

11. Gurtler, V. 1993. Typing of Clostridium difficile strains by PCR amplification of variable length 16S-23S rDNA spacer region. J. Gen. Microbiol. 139:30893097.

12. Harris, B. L. 1995. Air quality/wind erosion dynamics of the Sierra Blanca biosolid application area, p. 5.1-5.10. In Proceedings of the Effects of Land Application of Biosolids in the Arid and Semi-Arid West. U.S. Environmental Protection Agency, Fort Collins, Colo.

13. Hill, R. T., I. T. Knight, M. S. Anikis, and R. R. Colwell. 1993. Benthic distribution of sewage sludge indicated by Clostridium perfingens at a deepocean dump site. Appl. Environ. Microbiol. 59:47-51.

14. Hussong, D., W. D. Burge, and N. K. Enkiri. 1985. Occurrence, growth, and suppression of salmonellae in composted sewage sludge. Appl. Environ. Microbiol. 50:887-893.

15. Huysman, F., B. V. Renterghem, and W. Verstraete. 1992. Antibiotic resistant sulphite reducing clostridia in soil and groundwater as indicator of manuring practices. Water Air Soil Poll. 69:243-255.

16. Izjerman, M., J. Falkinham, and C. Hagedorn. 1993. A liquid colorimetric presence absence coliphage detection method. J. Virol. Methods 45:229-234.

17. Jakubowski, W. 1985. USEPA sponsored epidemiological studies of health effects associated with the treatment and disposal of wastewater and sewage sludge, p. 140-153. In J. C. Block, A. H. Havelaar, and P. L'Hermite (ed.) Epidemiological studies of risks associated with the agricultural use of sewage sludge: knowledge and needs. Elsevier Applied Science Publishers, London.

18. Juozaitis, A., K. Willeke, S. A. Grinshpun, and J. A. Donelly. 1994. Impaction onto a glass slide or agar versus impingement into a liquid for the collection and recovery of airborne microorganisms. Appl. Environ. Microbiol. 66:861870

19. Kromoredjo, P., and R. S. Fujioka. 1991. Evaluating three simple methods to assess the microbial quality of drinking water in Indonesia. Environ. Toxicol. Water Qual. 6:259-270.

20. Lembke, I. I., R. N. Kniseley, R. C. Van Nostrand, and M. D. Hale. 1981. Precision of the all glass impinger and the Andersen microbial impactor for air sampling in solid waste facilities. Appl. Environ. Microbiol. 42:222-225.

21. Lighthart, B., and B. T. Shaffer. 1995. Airborne bacteria in the atmosphere surface layer: temporal distribution above a grass seed field. Appl. Environ. Microbiol. 61:1492-1496.

22. McLamarra, J., and J. Pruitt. 1995. Beneficial reuse in the southeast. Ind. Wastewater 3(2):22-24.

23. Pepper, I. L., K. L. Josephson, R. L. Bailey, M. D. Burr, and C. P. Gerba. 1993. Survival of indicator organisms in Sonoran Desert soil amended with sewage sludge. J. Environ. Sci. Health A28(6):1287-1302.

24. Rosas, I., C. Calderón, M. Ulloa, and J. Lacey. 1993. Abundance of airborne Penicillium CFU in relation to urbanization in Mexico City. Appl. Environ. Microbiol. 59:2648-2652.

25. Scanlan, J. W., P. J. Psaris, R. D. Kuchewither, M. Nelson, M. Metcalf, R. S. Reinero, T. G. Akero, B. P. Flynn, P. L. Schafer, and J. M. Kelly. 1989 Review of EPA sewage sludge technical regulations. J. Water Pollut. Control Fed. 61:1206-1213.

26. Semenza, R. 1995. California food processors turn to land application. Ind. Wastewater 3(2):25-26.

27. Sinton, L. W., R. J. Davies-Colley, and R. G. Bell. 1994. Inactivation of enterococci and fecal coliforms from sewage and meatworks effluents in seawater chambers. Appl. Environ. Microbiol. 60:2040-2048.

28. Sosebee, R. E. 1994. General climate and weather patterns of the Chihuahuan Desert. Annual report on the basic and applied research on the beneficial reuse of biosolids on the Sierra Blanca Ranch. Texas Tech University, Lubbock.

29. Stewart, S. L., S. A. Grinshpun, K. Willeke, S. Terzieva, V. Ulevicius, and J. Donnelly. 1995. Effect of impact stress on microbial recovery on an agar surface. Appl. Environ. Microbiol. 61:1232-1239. 